\title{
Abundance and diversity of soil invertebrate macro-fauna in different land uses at Shenkolla watershed, South Central Ethiopia
}

\author{
Belayneh Bufebo ${ }^{1,2^{*}}$ D, Eyasu Elias ${ }^{2}$ and Emana Getu ${ }^{3}$
}

\begin{abstract}
Background: Land use can exert a strong influence on the abundance, diversity, and community composition of soil macro-fauna. This study was conducted to evaluate the effects of four land use types on the abundance and diversity of soil invertebrate macro-fauna communities. These land uses include forest land, grazing land, crop cultivated outfields, and homestead garden fields present at Shenkolla watershed, south central Ethiopia. Monolith sampling of soil macro-fauna was done according to the standard of Tropical Soils Biology and Fertility Institute (TSBF) procedure. Five sampling points were chosen in each land use type and small monolith $(25 \times 25 \times 30 \mathrm{~cm})$ was dug out at $5-\mathrm{m}$ interval along a transect with randomly positioned starting point, but perpendiculars to the slope. A total of 20 monoliths ( 4 treatments $\times 5$ replications) were taken across all the land use types. Sampling of SIMF was carried out in April 2019 where soil macro-faunas are known to be more active. To evaluate the SIMF community eight parameters were measured: Shannon-Wiener index, Simpson diversity index, Pielou's measure of evenness, Margalef's diversity index, the Number of Occurrence Index, Relative abundance, Density (individuals per square meter) of each taxon and density of all SIMF and Bray-Curtis similarity index. The data were further analyzed using ANOVA and a general linear model to determine the variation and the influence of land use type, respectively.

Results: In general, 332 individuals, 10 orders, 12 families, and 15 species were identified, from the collected samples. There were significant differences $(p<0.05)$ among the four land use types for SIMF except wireworm, spiders, and millipedes. Overall abundance and diversity were lowest in the crop cultivated outfields and highest in homestead garden fields and forest land. Bray-Curtis' similarity was highest between the sampled sites s16 and s19 with in the forest land, and lowest (2\%) between sites s1 (crop cultivated out fields) and s14 (homestead garden fields).

Conclusion: The results revealed that the diversity of SIMF was positively influenced by forest land and homestead garden fields and negatively influenced in grazing land and cultivated outfields. Therefore, maintenance of a continuous litter cover at the surface and application of a wide range of organic fertilizers (farmyard manure, household refuse, and compost) is very much critical to prevent the decrease in diversity of SIMF.
\end{abstract}

Keywords: Abundance, Diversity, Land use types, Monolith, Soil invertebrate macro-faunas

\footnotetext{
*Correspondence: belaytumma@gmail.com

'Department of Natural Resource Management, Wachemo University, P.O.

Box 667, Hosanna, Ethiopia

${ }^{2}$ Center for Environmental Science, College of Natural and Computational

Sciences, Addis Ababa University, Addis Ababa, Ethiopia

Full list of author information is available at the end of the article
}

Springer Open

(C) The Author(s). 2021 Open Access This article is licensed under a Creative Commons Attribution 4.0 International License, which permits use, sharing, adaptation, distribution and reproduction in any medium or format, as long as you give appropriate credit to the original author(s) and the source, provide a link to the Creative Commons licence, and indicate if changes were made. The images or other third party material in this article are included in the article's Creative Commons licence, unless indicated otherwise in a credit line to the material. If material is not included in the article's Creative Commons licence and your intended use is not permitted by statutory regulation or exceeds the permitted use, you will need to obtain permission directly from the copyright holder. To view a copy of this licence, visit http://creativecommons.org/licenses/by/4.0/. 


\section{Background}

Land use can exert a strong influence on the abundance, diversity, and community composition of soil macrofauna (Barros, Pashanasi, Constantino, \& Lavelle, 2002). As land use changes, so do species compositions and distributions. Land use changes and intensification are severe enough to influence plant communities, and it is likely that they trickle down to soil food webs and change linkages between above and below-ground communities (Wardle et al., 2004). In addition, annual cropping systems decrease the diversity and abundance of soil fauna communities due to soil disturbance and the absence of a permanent soil cover required for the staying alive of the soil organisms (Barrios, 2007; Rossi et al., 2010). When macro-fauna communities of important functional groups are affected by land use and land cover change, biodegradation of organic residues and essential ecosystem functions may also suffer (Moreira, Huising, \& Bignell, 2008). Soil macro-fauna are also thought to be influenced by unsustainable land management such as overgrazing, fire, deforestation, pollution, soil erosion, and depletion of fertility (Bignell et al., 2005).

The main features of forest land and homestead garden field are that minimal soil disturbance and better soil cover. These features create more favorable conditions for the development of soil organisms. While these features are practically absent in grazing land and cropcultivated out fields, resulting in higher soil degradation, increased compaction, and the lack of food, especially the absence of cover necessary for the survival of the soil organisms (Moreira et al., 2008; Rossi et al., 2010).

The SIMF distribution, abundance, and diversities are known to vary depending on residue inputs and soil management practices (Brown et al., 2004; Manhães, Gama-Rodrigues, Moço, \& Gama-Rodrigues, 2013; Mutema, Mafongoya, Nyagumbo, \& Chikukura, 2013). It can therefore be hypothesized that different land management practices have an effect on SIMF differentially. Due to the lack of previous research in Shenkolla watershed, there is information gap on local SIMF assemblages in different land use types. So investigation of the potential of SIMF as a bioindicator in different land use systems under this specific watershed is required to come up with conclusion that the land use change affects the abundance and diversity of SIMF. Thus, in view of this, the present study was conducted to evaluate the pattern of abundance and diversity of SIMF in four land use types at Shenkolla watershed, south central Ethiopia.

\section{Methods}

\section{Description of the study area}

The study was conducted within four main land use types: forest land, homestead garden field, grazing land, and cultivated outfield at Shenkolla watershed which is located in the eastern part of Soro district. Geographically, the area falls within the coordinates of $7^{\circ} 24^{\prime} 30^{\prime \prime}-$ $7^{\circ} 27^{\prime} 0^{\prime \prime} \mathrm{N}$ latitude and $37^{\circ} 43^{\prime} 30^{\prime \prime}-37^{\circ} 46^{\prime} 30^{\prime \prime} \mathrm{E}$ longitude (Fig. 1). The altitude ranges from 2200 to 2830 m.a.s.l.

The climate of the watershed is characterized generally as tepid sub-moist mid highland with long-term average rainfall of about $1107 \mathrm{~mm}$ with bi-modal pattern having light rainy season is usually from March to May and the heavy rainy season is from June to September. The annual average temperature is $17.2^{\circ} \mathrm{C}$ (Fig. 2).

The dominant soil type is Nitisol in all land use types. According to the rating proposed by (Landon, 1991), the soil $\mathrm{pH}$ of the watershed is moderately acidic in the cultivated outfields (5.80) but neutral under forest (7.20), homestead garden fields (6.83), and grazing lands (6.57) (Bufebo \& Elias, 2020). This suggesting the intensive land use including the application of mineral fertilizers in cultivated outfields led to acidification.

Mixed crop-livestock system is the major source of livelihood for the community in the study watershed. The system is noted for its high population densities (200-350 persons per kilometer square). Also, there is a severe land shortage (average holdings of 0.5 ha for a family of 8 persons) along with intensive cultivation. Forest and grazing lands are communally owned and managed while the arable lands are individually owned (Bufebo \& Elias, 2020).

Livestock husbandry is based on free grazing on communal grazing lands. Free grazing' is an age-old traditional system which allows owners to indiscriminately graze their livestock on communal land. Especially during the cropping season, all livestock are confined to the scarce grazing lands which for 5-6 months of the year are subject to immense grazing pressure. Large herd size on small grazing lands and poor pasture management increased the pressure on grazing land of the study area (Elias, 2016). As a result, the animals cannot get enough fodder to stay healthy and in good condition; similarly, the natural vegetation has no chance to recover at any time of year. There is no reseeding effect, the most palatable grasses and legumes have disappeared, and bare patches have developed, giving room for accelerated soil erosion and severe dissection by rills and gullies (Bufebo \& Elias, 2020).

In the study area, agricultural cultivation (cultivated outfields and homestead garden fields) is started approximately 40 years ago. Arable lands are composed of the intensively cultivated outfields (crop lands) and well-managed homestead garden fields. Homestead garden fields are covered with staple food crop such as enset (Ensete ventricosum (Welw.) Cheesman) and trees such as avocado (Persea Americana Mill.), Croton macrostachyus Hochst. ex Delile, 


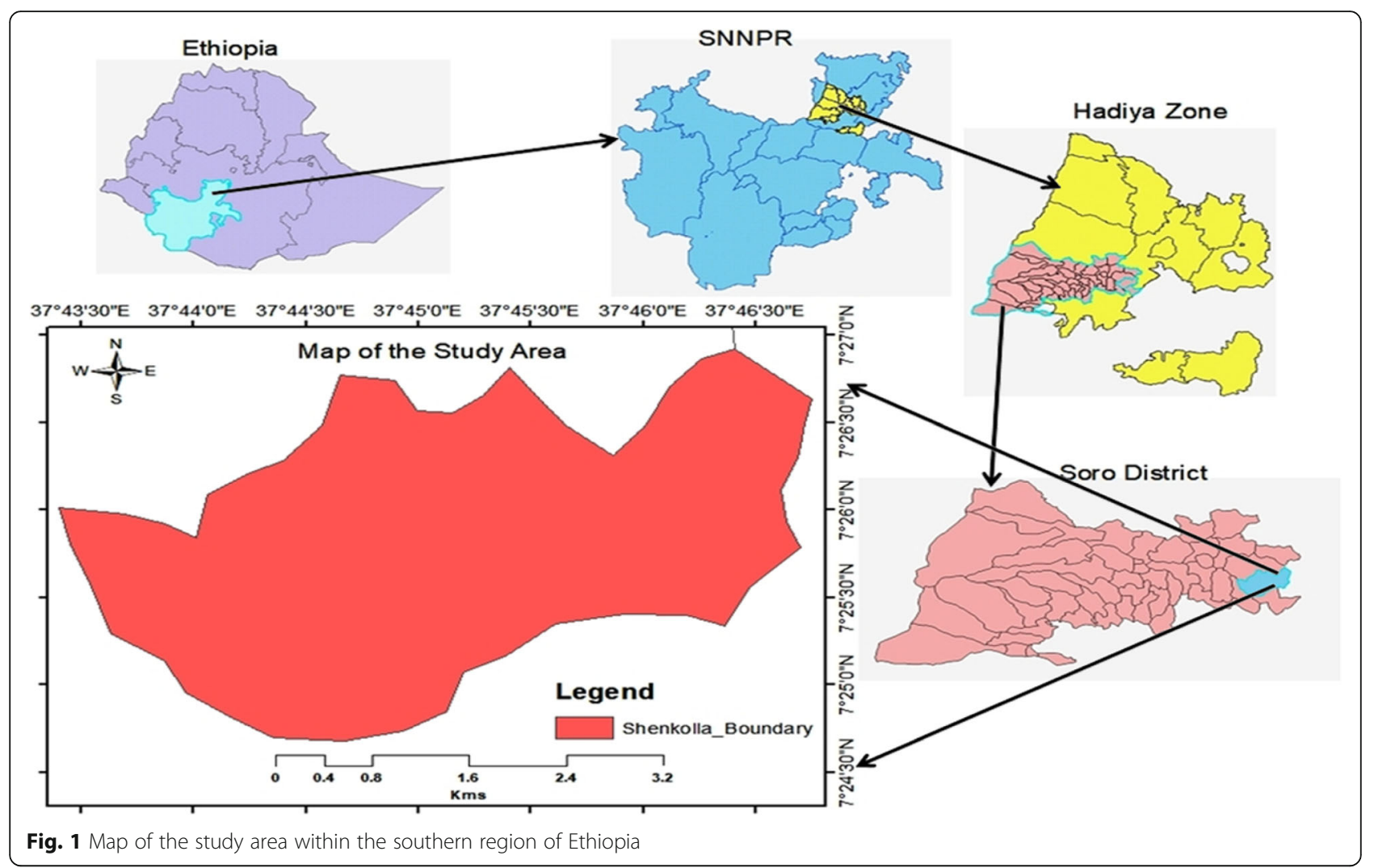

and Erythrina spp. with undergrowth of some vegetables and spices forming multistory home garden (Elias, 2018). The distant cultivated outfields are planted with cereals, wheat (Triticum aestivum L.), maize (Zea mays L.), barley (Hordeum vulgare L.), sorghum (Sorghum bicolor (L.)Monench), and teff (Eragrostis tef (Zucc.) Trotter) that form the co-staples with enset.

Soil fertility management is clearly differentiated between the cultivated outfields and homestead garden fields. Hoeing and incorporation of farmyard manure in homestead garden fields are distinctly different from the plough-based complex system in the intensively cultivated outfields
(Elias, 2016). The homestead garden fields receive the application of a wide range of organic fertilizers (farmyard manure, household refuse, compost, and leaf litter). Soil fertility in the homestead garden fields is maintained through the application of approximately nine tons per hectare annually of farmyard manure on average, while the crop cultivated outfields are treated with a dose of less than prescribed amounts of mineral fertilizer with an average rate of $50 \mathrm{~kg}$ urea and $65 \mathrm{~kg} / \mathrm{ha}$ DAP (Di-ammonium phosphate: $18 \% \mathrm{~N}, 46 \%$ P2O5) (Elias, Okothc, \& Smalingd, 2019). Crop residue removal is another problem that causes soil fertility decline in cultivated outfields. As the

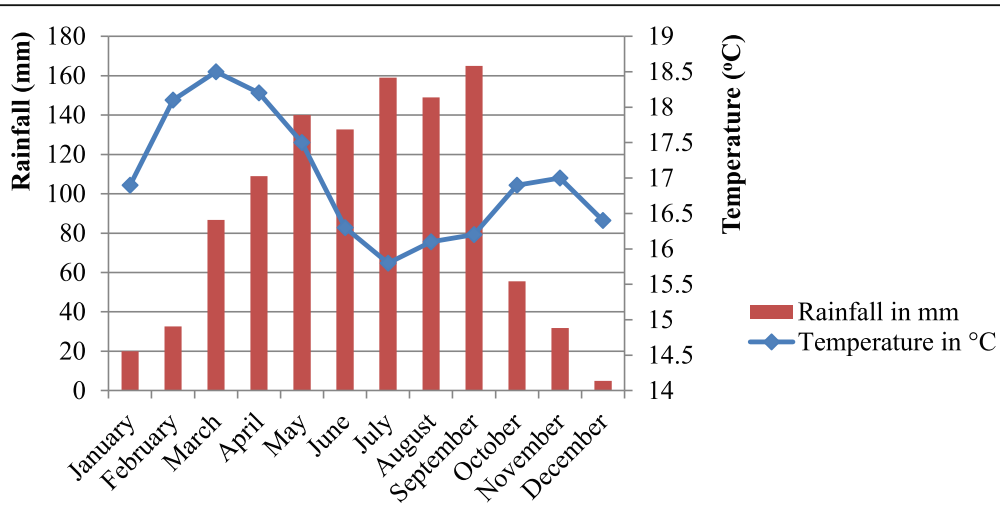

Fig. 2 Mean monthly rainfall and temperature of the of study area 
result, cultivated outfields are largely depleted of soil fertility but homestead garden fields are enriched.

The differences in land use and management practices indicated that there was a difference in extent of water erosion in the study area. Field observation indicated that the presence of slight water erosion in forest land and homestead garden fields and accelerated water erosion in grazing land and cultivated outfields at the study site. This shows that the susceptibility of the soils of cultivated outfields and grazing land to water erosion (Bufebo \& Elias, 2020).

\section{Sampling methods and experimental design}

Sampling was conducted in April 2019 at the beginning of slight rainfall locally called belg when soil macrofaunas are known to be more active (Seeber et al., 2005, Tondoh \& Lavelle, 2005,). Monolith sampling of soil macro-fauna was done according to the standard of Tropical Soils Biology and Fertility Institute (TSBF) procedure (Bignell et al., 2008). Five sampling points were chosen at each land use type. At each sampling point, one small monolith $(25 \times 25 \times 30 \mathrm{~cm})$ was dug out at 5$\mathrm{m}$ interval along a transect with randomly positioned starting points but perpendiculars to the slope (modified TSBF protocol, Anderson \& Ingram, 1993). The total of 20 sampling points was dug out by taking 5 representative monoliths from each land use type. Each sample was taken to the sampling base and hand sorted, removing all the macro-fauna $>2 \mathrm{~mm}$ in diameter that were visible to the naked eye (Lavelle, Senapati, \& Barros, 2003). Soil macro-faunas were counted and preserved in vials filled with $70 \%$ alcohol and labeled. The soil was returned to the site of removal after the extraction of soil organisms to minimize destruction and fragmentation of the vulnerable soils of different land use types.

\section{Identification of soil macro-fauna}

The sampled organisms were then taken to the Insect Sciences laboratory of Addis Ababa University for identification. Species of soil invertebrate macro-fauna (SIMF) were identified in laboratory using identification key and pictures (Eaton \& Kaufman, 2007; Zettler et al., 2016). Macro-fauna abundance was determined in four land use types according to the following main groups: earthworms (Haplotaxida), termites (Isoptera), ants (Hymenoptera), and other macro-fauna. Finally, soil organisms were separated into 15 taxonomic species; density and abundance of each species in four land use classes were computed.

\section{Statistical analysis}

Eight community parameters, including Shannon-Wiener index, Simpson index, Pielou's index of evenness, Margalef's diversity index, Bray-Curtis similarity index, the number of occurrence index, relative abundance, and density, were computed for land use types and used to compare SIMF diversity across the land uses.

\section{Shannon and Weiner index (Shannon \& Weaver, 1949)}

Shannon-Weiner Diversity Index $\left(H^{\prime}\right)$ was used as a measure of species abundance and richness to quantify the diversity of the SIMF. The $H^{\prime}$ was calculated using the Shannon and Weaver (1949) is given by the equation:

$$
H^{\prime}=\left(-\sum \mathrm{Pi} * \operatorname{Ln}(\mathrm{Pi})\right)
$$

where $H^{\prime}$ is Shannon-Wiener Diversity Index, Pi is the proportion of each species of SIMF in the sample, and $\mathrm{Ln}(\mathrm{Pi})$ is the natural logarithm of this proportion.

\section{Simpson index (Simpson, 1949)}

Simpson Index measures the probability of any two individuals drawn from noticeably large community belonging to different species. It was measured by the following formula:

$$
D=1-\frac{\sum n(n-1)}{N(N-1)}
$$

where $n$ is the total number of SIMF of a particular species and $N$ is the total number of SIMF of all species.

\section{Pielou's measure of evenness (Pielou, 1966)}

Pielou's evenness index $\left(J^{\prime}\right)$ was calculated using the ratio of observed diversity to maximum diversity using the equation.

$$
J^{\prime}=\frac{H^{\prime}}{\operatorname{Ln} S}
$$

where $J^{\prime}$ is evenness index, $H^{\prime}$ is the Shannon-Wiener Diversity Index, and $\operatorname{Ln} S$ is the natural $\log$ of a total number of observed species.

\section{Margalef's diversity index (Margalef, 1968)}

Margalef's diversity index is calculated using the formula:

$$
d=\frac{S-1}{\operatorname{Ln} N}
$$

where $d=$ Margalef's diversity index, $S=$ number of species, and $N=$ number of individuals.

Bray-Curtis similarity index (Bray \& Curts, 1957)

Bray and Curts (1957) standardized the Manhattan metric so that it has a range from 0 (similar) to 1 (dissimilar). Bray-Curtis coefficient is computed by dividing the shared abundance by the total abundance. For two 
plots $i$ and $k, B_{i, k}$ was computed as follows (Bray \& Curts, 1957):

$$
B_{i, k}=\frac{\sum_{j=1}^{p}\left|S_{i j}-S_{K j}\right|}{\sum_{j=1}^{p} S_{i j}+\sum_{j=1}^{p} S_{k j}}
$$

where $B_{i, k}$ is Bray-Curtis coefficient, $s i j$ and $s k j$ are the number of species of $j$ in land uses $i$, and $k$ respectively; $p=$ total number of species.

\section{Number of occurrence index (NOI)}

This is the total number of individuals of each species in a sample, expressed as a percentage of the total number of individuals of all species in the sample.

$$
\mathrm{NOI}=\frac{A}{B} \times 100
$$

where $A=$ number of individual of each species in the sample and $B=$ total number of individual of all species in the sample.

\section{Relative abundance}

The relative abundance of SIMF per land use class was determined using the following formula

$$
\text { Relative abundance }=\frac{n}{N}
$$

where $n$ is the total number of SIMF of a particular species and $N$ is the total number of SIMF of all species.

\section{Density of SIMF}

The density of SIMF was determined using the following formula

$$
\text { Density }=\frac{c}{\mathrm{~m}^{2}}
$$

where $c$ is the total number of SIMF of a particular species in one square meter of soil and $\mathrm{m}^{2}$ is the area of soil calculated by multiplying $1 \mathrm{~m}$ by $1 \mathrm{~m}$.

One-way analysis of variance (ANOVA) was performed to compare the variations in SIMF abundance among different land uses. A generalized linear models (GLMs) analysis was conducted to determine the influence of land use class (fixed factor), with 4 levels: (i) cultivated out fields, (ii) grazing lands, (iii) homestead garden fields, and (iv) forest lands, on the SIMF abundance (response variable). Statistical package for SPSS v.16.0 (SPSS (Statistical Package for Social Science), 2007) for windows was used to carry out ANOVA and GLMs.

\section{Results}

Composition and occurrence of SIMF community

A total of 332 individuals and 15 species, belonging to 12 families and 10 orders were then identified, from the four land use types (Table 1). Ants, beetle adults, earthworms, spiders, and millipedes were found in all land use types. Wireworms (Coleoptera: Elateridae) and earwigs were only sampled in the forest land. Beetle larvae, centipede, and snails were not sampled in the crop cultivated outfield and grazing land use types, while majority were found in the forest lands (15 species) and homestead garden fields (12 species) (Table 1). This study confirmed that earth worms, termites, beetle adults, and ants were dominant species in the study watershed. The NOI of SIMF in the homestead garden field was $44.58 \%$ value 3.4 times larger than that in the cultivated outfields (Table 2).

\section{Density and relative abundance of SIMF}

The mean density of earthworms, termites, adult beetles, and ants was relatively high (141.6, 37.60, 19.2, 19.2 individuals $/ \mathrm{m}^{2}$, respectively) showing their dominance over other species (Table 2). The homestead garden fields had high densities of earthworms (230.4 individuals $/ \mathrm{m}^{2}$ ) ants $\left(48.00\right.$ individuals $\left./ \mathrm{m}^{2}\right)$, beetle adult (44.80 individuals $/ \mathrm{m}^{2}$ ), and beetle larva (41.60 individuals $/ \mathrm{m}^{2}$ ) (Fig. 3). The forest lands had a high density of termites $(83.20$ individuals $/ \mathrm{m}^{2}$ ). However, the lowest densities were observed in the cultivated outfields (Fig. 3). Significant variations among land use types were detected for density of most SIMF groups $(P<0.05)$, except for wireworm, spiders, and millipedes ( $P=0.83,0.70,0.74$, respectively) (Table 3). The homestead garden fields had a significantly higher mean density of SIMF than the forest, cultivated outfields and grazing lands (Table 3). The mean density of earthworms and ants were significantly highest in the homestead garden fields $(230.4 \pm 4.59,48.00 \pm$ 25.29 , respectively). The mean density of termites reached its maximum $(83.23 \pm 9.51)$ in the forest land use (Table 3). The earthworms were ranked 1st as this group has the highest relative abundance (0.533), while wireworms were ranked 10th since they had the lowest relative abundance (0.006) (Table 2).

\section{Diversity and similarity of SIMF across land use types}

The SIMF communities within stress conditions, in the crop cultivated outfields and grazing lands, exhibiting lower diversity than stable communities, in the homestead garden fields and forest lands (Table 2). Values of species richness, Simpson diversity, evenness, and Margalef diversity were highest for forest land use $(15,0.83,0.428$, 2.56 , respectively) while they turned to be lowest for cultivated outfields $(5,0.22,0.075,1.06$, respectively) (Table 2 ). Species richness is high in forest land whereas low in 
Table 1 Composition and distribution of soil invertebrate macro-fauna in different land use types at Shenkolla watershed, south central Ethiopia

\begin{tabular}{|c|c|c|c|c|c|c|c|c|}
\hline \multirow{2}{*}{$\begin{array}{l}\text { Common } \\
\text { name }\end{array}$} & \multicolumn{4}{|l|}{ Taxa } & \multicolumn{4}{|l|}{ Distribution } \\
\hline & Class & Order & Family & Scientific name & $\begin{array}{l}\text { Crop cultivated } \\
\text { outfield }\end{array}$ & $\begin{array}{l}\text { Grazing } \\
\text { land }\end{array}$ & $\begin{array}{l}\text { Homestead } \\
\text { garden field }\end{array}$ & $\begin{array}{l}\text { Forest } \\
\text { land }\end{array}$ \\
\hline \multirow[t]{2}{*}{ Earth worm } & Clitellata & Haplotaxida & Lumbricidae & $\begin{array}{l}\text { Aporrectodea calignosa } \\
\text { (Savigny, 1826) }\end{array}$ & + & + & + & + \\
\hline & & & & $\begin{array}{l}\text { Lumbricus terrestris } \\
\text { Linnaeus, } 1758\end{array}$ & - & - & + & + \\
\hline \multirow[t]{2}{*}{ Beetle adult } & Insecta & Coleoptera & Scarabaeidae & Aphodius sp. & - & - & + & + \\
\hline & & & & Copris incertus Say, 1835 & + & + & + & + \\
\hline $\begin{array}{l}\text { Beetle } \\
\text { larvae }\end{array}$ & & & & Copris incertus Say, 1835 & - & - & + & + \\
\hline \multirow[t]{2}{*}{ Beetle adult } & & & Crowsoniellidae & $\begin{array}{l}\text { Crowsoniella relicta } \\
\text { Pace, } 1975\end{array}$ & - & + & + & + \\
\hline & & & Elateridae & $\begin{array}{l}\text { Pheletes quercus } \\
\text { (A. G. Olivier, 1790) }\end{array}$ & - & - & + & + \\
\hline Wireworm & & & & $\begin{array}{l}\text { Ctenicera glauca } \\
\text { (Germar, 1843) }\end{array}$ & - & - & - & + \\
\hline Ant & & Hymenoptera & Formicidae & $\begin{array}{l}\text { Pheidole megacephala } \\
\text { (Fabricius, 1793) }\end{array}$ & + & + & + & + \\
\hline Termite & & Isoptera & Rhinotermitidae & $\begin{array}{l}\text { Reticulitermes flavipes } \\
\text { (Kollar, 1837) }\end{array}$ & - & + & + & + \\
\hline Earwig & & Dermaptera & Forficulidae & $\begin{array}{l}\text { Forficula auricularia } \\
\text { Linnaeus, } 1758\end{array}$ & - & - & - & + \\
\hline Grasshopper & & Orthoptera & Acrididae & $\begin{array}{l}\text { Aulocara elliotti } \\
\text { (Thomas, 1870) }\end{array}$ & - & + & + & + \\
\hline Millipede & Diplopoda & Spirostreptida & Spirostreptidae & $\begin{array}{l}\text { Archispirostreptus gigas } \\
\text { (Peters, 1855) }\end{array}$ & + & + & + & + \\
\hline Centipede & Chilopoda & Lithbiomorpha & Lithobiidae & $\begin{array}{l}\text { Lithobius forficatus } \\
\text { (Linnaeus, 1758) }\end{array}$ & - & - & + & + \\
\hline Spider & Arachnida & Araneae & Linyphiidae & $\begin{array}{l}\text { Frontinella pyramitela } \\
\text { (Walckenaer, 1841) }\end{array}$ & + & + & + & + \\
\hline Snail & Gastropoda & Stylommatophora & Achatinidae & $\begin{array}{l}\text { Achatina fulica } \\
\text { (Férussac, 1821) }\end{array}$ & - & - & + & + \\
\hline
\end{tabular}

+ indicates present, - indicates absent

cultivated outfields. Shannon diversity of SIMF showed its maximum value in the homestead garden fields (0.279) followed by forest lands $(0.262)$ and the minimum value in the cultivated outfields (0.121) (Table 2).

From the data processed according to Bray-Curtis similarity index (Table 4), it is evident that the largest dissimilarity of SIMF communities (0.98) is between the sampled sites s1 (crop cultivated outfields) and s14 (homestead garden fields), and the smallest dissimilarity (0.02) is between s16 and s19 within the forest lands. These means that the species common to s1 and s14 is small (only $2 \%$ similarity). The two sample sites ( $\mathrm{s} 1$ and s14) share low number of species in common as compared with s16 and s19 (98\% similarity) (Table 4).

\section{The effect of land use on abundance of SIMF}

The most numerous macro-fauna group present across all land use types were earthworms with a total abundance of 177 across all land use types. This constitutes $53.3 \%$ of all macro-fauna. Termites were with a total abundance of 47 (14.2\%) of all macro-fauna, and all the rest macrofauna constituted an abundance of 108 (32.5\%) of total macro-fauna (Table 5). Earthworms were the dominant group of SIMF, followed by termites. High abundance of earthworms (72) was recorded in the homestead garden fields. The abundance of termites reached its maximum (26) in the forest land use (Table 5). Values of an abundance of SIMF were in the order of homestead garden fields $>$ forest land $>$ grazing land $>$ cultivated out fields (Table 5). Overall, the abundance of SIMF was lowest in crop cultivated outfields and highest in homestead garden fields followed by forest land (Table 5).

The GLM model indicated that there was no significant effect of land use on the SIMF groups, except earthworm (Table 6). Since we had multiple fixed effects, then the significance of the overall model and the 
Table $\mathbf{2}$ The diversity parameters of SIMF at Shenkolla watershed, south central Ethiopia

\begin{tabular}{|c|c|c|c|c|c|c|c|c|}
\hline & & \multirow{2}{*}{$\begin{array}{l}\text { Density } \\
\text { (individuals } / \mathrm{m}^{2} \text { ) }\end{array}$} & \multirow{2}{*}{$\begin{array}{l}\text { Relative } \\
\text { abundance }\end{array}$} & \multirow[t]{2}{*}{ Rank } & \multicolumn{4}{|l|}{ Occurrence index } \\
\hline & & & & & $\begin{array}{l}\text { Crop cultivated } \\
\text { outfields }\end{array}$ & $\begin{array}{l}\text { Grazing } \\
\text { land }\end{array}$ & $\begin{array}{l}\text { Homestead } \\
\text { garden field }\end{array}$ & $\begin{array}{l}\text { Forest } \\
\text { land }\end{array}$ \\
\hline \multirow[t]{13}{*}{ SIMF group } & Earthworms & 141.6 & 0.533 & 1 & $88.63(39)$ & $79.1(53)$ & $48.65(72)$ & $17.81(13)$ \\
\hline & Beetle larvae & 13.6 & 0.051 & 4 & $0(0)$ & $0(0)$ & $8.78(13)$ & $5.45(4)$ \\
\hline & Beetle adults & 19.20 & 0.072 & 3 & $2.27(1)$ & $2.98(2)$ & $10.14(15)$ & $8.23(6)$ \\
\hline & Wireworms & 1.60 & 0.006 & 10 & $0(0)$ & $0(0)$ & $0(0)$ & $2.74(2)$ \\
\hline & Spiders & 6.40 & 0.024 & 7 & $4.55(2)$ & $4.48(3)$ & $1.35(2)$ & $1.37(1)$ \\
\hline & Ants & 19.20 & 0.072 & 3 & $2.27(1)$ & $5.97(4)$ & $10.14(15)$ & $5.45(4)$ \\
\hline & Termites & 37.60 & 0.145 & 2 & $0(0)$ & $2.98(2)$ & $12.84(19)$ & $35.62(26)$ \\
\hline & Millipedes & 8.80 & 0.033 & 5 & $2.27(1)$ & $4.48(3)$ & $2.03(3)$ & $5.45(4)$ \\
\hline & Centipedes & 7.20 & 0.027 & 6 & $0(0)$ & $0(0)$ & $4.05(6)$ & $4.11(3)$ \\
\hline & Earwigs & 3.20 & 0.012 & 9 & $0(0)$ & $0(0)$ & $0(0)$ & $5.45(4)$ \\
\hline & Snails & 3.20 & 0.012 & 9 & $0(0)$ & $0(0)$ & $2.03(3)$ & $1.37(1)$ \\
\hline & Grasshoppers & 4.00 & 0.015 & 8 & $0(0)$ & $1.49(1)$ & $0(0)$ & $6.85(5)$ \\
\hline & \multicolumn{4}{|l|}{ Total } & $13.25(44)$ & $20.18(67)$ & $44.58(148)$ & $22.00(73)$ \\
\hline \multirow[t]{6}{*}{ Diversity parameter } & \multicolumn{4}{|c|}{ Overall abundance } & 44 & 67 & 148 & 73 \\
\hline & \multicolumn{4}{|c|}{ Species richness } & 5 & 7 & 12 & 15 \\
\hline & \multicolumn{4}{|c|}{ Shannon diversity index } & 0.121 & 0.174 & 0.279 & 0.262 \\
\hline & \multicolumn{4}{|c|}{ Simpson diversity index } & 0.22 & 0.37 & 0.6 & 0.83 \\
\hline & \multicolumn{4}{|c|}{ Pielous measure of Evenness } & 0.075 & 0.097 & 0.127 & 0.428 \\
\hline & \multicolumn{4}{|c|}{ Margalef diversity index } & 1.06 & 1.19 & 1.6 & 2.56 \\
\hline
\end{tabular}

Number in the parenthesis indicates frequency

significances of the coefficients were different. However, land use significantly affected the overall model, which considers all effects together (GLM: F-statistic $=7.595$, $\mathrm{df}=36, p$ value $1.468 \mathrm{e}-06$ ) (Table 6). The model revealed the significant effects of land use on over all macro-fauna abundance. This indicated that there was difference in distribution and composition of SIMF among the four land uses. Land use was indeed more important in explaining the abundance of macro-fauna in Shenkolla watershed.

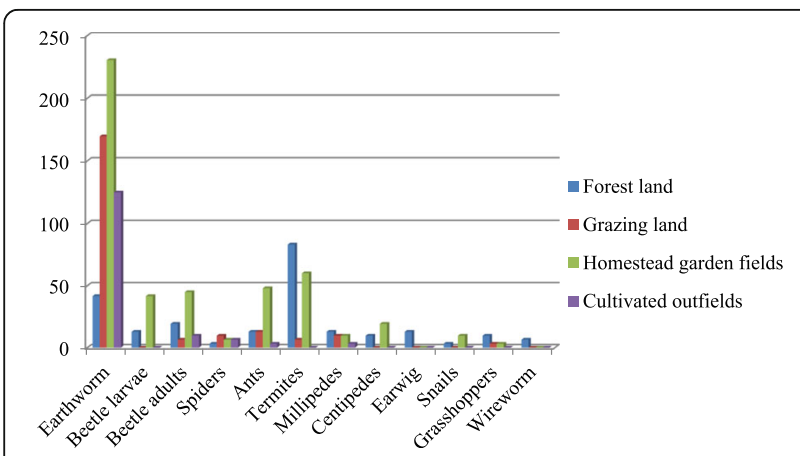

Fig. 3 Density of soil invertebrate macro-fauna in different land use types at Shenkolla watershed, south central Ethiopia

\section{Discussion}

Composition and occurrence of SIMF community

The SIMF community clearly responded to the environmental disturbance induced by unsustainable land use management. These groups of SIMF living in forest and homestead garden fields were favored, possibly via the large production, and/or better quality of litter. This owing to the fact that high organic matter content under forest and homestead garden fields which provided substrates for the soil organisms, likely reduces the negative effects of soil acidity on soil organisms (Ayuke et al., 2011; Beare, Reddy, Tian, \& Srivastava, 1997). Also, the crop cultivated outfields had higher soil acidity concentrations and low organic matter content (Bufebo \& Elias, 2020) considered to be "not convenient" for many SIMF.

\section{Diversity and similarity of SIMF across land use types}

Homestead garden fields and forest lands had more species diversity explaining the fact that unregulated agricultural expansion into forest land had a negative impact on SIMF species diversity. Diversity decreased gradually with an increasing intensification of land use in the system. This might be hypothesized that the low vegetation diversity led to impoverished SIMF species diversity and high vegetation diversity led to rich SIMF diversity. 
Table 3 mean density (individuals $/ \mathrm{m}^{2}$ ) with standard deviation of SIMF sampled at Shenkolla watershed

\begin{tabular}{|c|c|c|c|c|c|c|c|c|}
\hline \multirow[t]{2}{*}{ SIMF group } & \multicolumn{4}{|l|}{ Land use type } & \multicolumn{4}{|l|}{ ANOVA result } \\
\hline & Crop cultivated outfields & Grazing land & Homestead garden field & Forest land & Mean & $D f$ & $F$ value & $P$ value \\
\hline Earthworms & $124.80 \pm 80.32 a$ & $169.60 \pm 24.26 a$ & $230.40 \pm 64.59 b$ & $41.60 \pm 48.79 a b$ & $141.60 \pm 88.59$ & 3 & 7.77 & $0.002^{* *}$ \\
\hline Beetle larvae & $0.00 \pm 0.00 a$ & $0.00 \pm 0.00 a$ & $41.60 \pm 33.17 b$ & $12.80 \pm 28.62 \mathrm{ab}$ & $13.60 \pm 26.60$ & 3 & 4.01 & $0.026^{*}$ \\
\hline Beetle adults & $6.40 \pm 14.31 a$ & $6.4 \pm 8.76 a$ & $44.8 \pm 13.38 b$ & $19.20 \pm 7.15 c$ & $19.420 \pm 18.43$ & 3 & 19.95 & $0.000^{* * *}$ \\
\hline Wireworms & $0.00 \pm 0.00$ & $0.00 \pm 0.00$ & $0.00 \pm 0.00$ & $6.4 \pm 8.76$ & $1.6 \pm 4.92$ & 3 & 2.67 & $0.83 \mathrm{~ns}$ \\
\hline Spiders & $6.40 \pm 8.76$ & $9.60 \pm 8.76$ & $6.40 \pm 8.76$ & $3.20 \pm 7.15$ & $6.40 \pm 8.04$ & 3 & 0.48 & $0.698 \mathrm{~ns}$ \\
\hline Ants & $3.20 \pm 7.15 a$ & $12.80 \pm 13.38 a$ & $48.10 \pm 25.29 b$ & $12.80 \pm 20.86 a$ & $19.20 \pm 24.13$ & 3 & 5.96 & $0.006^{* *}$ \\
\hline Termites & $0.00 \pm 0.00 \mathrm{a}$ & $6.40 \pm 14.31 a$ & $60.80 \pm 13.38 b$ & $83.23 \pm 79.51 b$ & $37.60 \pm 52.24$ & 3 & 4.97 & $0.013^{*}$ \\
\hline Millipedes & $3.20 \pm 7.15$ & $9.60 \pm 21.46$ & $9.60 \pm 14.31$ & $12.80 \pm 7.15$ & $8.80 \pm 13.20$ & 3 & 0.42 & $0.74 \mathrm{~ns}$ \\
\hline Centipedes & $0.00 \pm 0.00$ & $0.00 \pm 0.00 \mathrm{a}$ & $19.20 \pm 13.38 b$ & $9.60 \pm 8.76 b$ & $7.20 \pm 10.98$ & 3 & 6.6 & $0.004^{* *}$ \\
\hline Earwigs & $0.00 \pm 0.00 a$ & $0.00 \pm 0.00 \mathrm{a}$ & $0.00 \pm 0.00 \mathrm{a}$ & $12.80 \pm 7.15 b$ & $3.20 \pm 6.56$ & 3 & 16 & $0.000^{* * *}$ \\
\hline Snails & $0.00 \pm 0.00 \mathrm{a}$ & $0.00 \pm 0.00 \mathrm{a}$ & $9.60 \pm 8.76 b$ & $3.20 \pm 7.15 b$ & $3.20 \pm 6.56$ & 3 & 3.2 & $0.05^{*}$ \\
\hline Grasshoppers & $0.00 \pm 0.00 a$ & $3.20 \pm 7.15 a$ & $3.20 \pm 7.15 a$ & $9.60 \pm 14.31 b$ & $4.00 \pm 9.39$ & 3 & 4.37 & $0.02^{*}$ \\
\hline
\end{tabular}

Values followed by the same letters within rows are not significantly different at $P<0.05$, ns $=$ non-significant; $* * * P<0.001 ; * * P<0.01 ; * P<0.05$

The effect of land use on density and abundance of SIMF The density of SIMF communities varied significantly in relation to the land use. In our study, an increase in density of SIMF in the forest and homestead garden fields was largely accounted by variations in litter quality and /or abundance, occurrence of vacant niches, good $\mathrm{pH}$, and moisture content at the soil surface (Bufebo \& Elias, 2020). This may be attributed to the variation of disturbance level in the habitats within these land use types on the community composition of SIMF (Ayuke et al., 2011; Barrios, 2007; Rossi et al., 2010).

Homestead garden fields and forest land had more species abundance explaining that the fact that unregulated agricultural expansion into forest land had a negative impact on the abundance of SIMF species. The abundance of SIMF was dramatically affected by grazing land and crop cultivated outfields. Similarly, (Decaëns, Lavelle, Jimenez, Escobar, \& Rippstein, 1994) reported that the abundance of soil macro-fauna tends to decrease to low levels in crop cultivated lands. The higher the vegetation diversity, so the ability to provide energy and food source for soil macro-fauna would be high. The higher the availability of energy and nutrients for soil macro-fauna, so growth and activity of soil macrofauna would be better (Negasa et al., 2017).

As intensification occurs in crop cultivated outfields, losses and stresses imposed by chemical contamination through use of herbicides and pesticides, as well as chemical imbalances through soil acidification resulted in gradual decrease in SIMF diversity (Elias, 2016). Moreover, continuous grazing and poor pasture management in grazing land of the study area led to soil degradation through nutrient depletion and compaction impaired soil biological functioning (Bufebo \& Elias, 2020). Similarly, (Muchane et al., 2012) reported that agricultural activities significantly affected the composition of macro-fauna community. In this study, increasing in abundance of earthworm (39) in crop cultivated out fields showed its more adaptability while earthworms have been found to be sensitive to disturbance (Lavelle et al., 1994). Several studies have noted abundant termite and earthworm populations in agricultural land uses, especially those with limited- or no-tillage management (Ayuke et al., 2009; Mutema et al., 2013). The relatively low abundance of SIMF noted within the crop cultivated field may result from the use of certain agricultural chemical inputs suggesting that technological intensification (Elias, 2016; New, 2005). Modifications of macro-fauna communities are known to have potential negative effects on soil functioning and on the sustainability of ecosystems (Decaëns et al., 2004). Although grazing land and cultivated outfields had negative impacts on the diversity and density of SIMF species, still significant numbers of species do exist on grazing land and cultivated outfields calling for the need to consider these land uses for conservation and maintenance of SIMF species.

SIMF are sensitive indicators of the nature of land use and management (Negasa et al., 2017). The homestead garden fields and forest land had higher abundance and diversity than any other type of land use. Biological activity is concentrated in the forest and homestead garden fields. This might be attributed by the availability of potential substrate and quality of the surface litter (Ayuke et al., 2009; Manhães et al., 2013). Additionally, the homestead garden fields receive the application of a wide range of organic fertilizers and partly decomposed leaves and twigs from multipurpose trees (Elias, 2016). This is an indication that these land uses may sustain sufficiently abundant and diverse communities to optimize the effects of these beneficial organisms (Brown et al., 1999). The quality of organic matter produced and the 
Table 4 Bray-Curtis' similarities between the 20 sampled sites of soil invertebrate macro-fauna at Shenkolla watershed, south central Ethiopia

\begin{tabular}{|c|c|c|c|c|c|c|c|c|c|c|c|c|c|c|c|c|c|c|c|c|}
\hline $\begin{array}{l}\text { S1 } \\
\text { (Cu) }\end{array}$ & $\begin{array}{l}\text { S1 } \\
\text { (Cu) }\end{array}$ & $\begin{array}{l}\text { S2 } \\
\text { (Cu) }\end{array}$ & $\begin{array}{l}\text { S3 } \\
(\mathrm{Cu})\end{array}$ & $\begin{array}{l}\text { S4 } \\
(\mathrm{Cu})\end{array}$ & $\begin{array}{l}\text { S5 } \\
(\mathrm{Cu})\end{array}$ & $\begin{array}{l}\text { S6 } \\
\text { (Gr) }\end{array}$ & $\begin{array}{l}\text { S7 } \\
\text { (Gr) }\end{array}$ & $\begin{array}{l}\text { S8 } \\
\text { (Gr) }\end{array}$ & $\begin{array}{l}\text { S9 } \\
\text { (Gr) }\end{array}$ & $\begin{array}{l}\text { S10 } \\
\text { (Gr) }\end{array}$ & $\begin{array}{l}\text { S11 } \\
\text { (Ho) }\end{array}$ & $\begin{array}{l}\mathrm{S} 12 \\
(\mathrm{Ho})\end{array}$ & $\begin{array}{l}\text { S13 } \\
\text { (Ho) }\end{array}$ & $\begin{array}{l}\text { S14 } \\
\text { (Ho) }\end{array}$ & $\begin{array}{l}\text { S15 } \\
\text { (Ho) }\end{array}$ & $\begin{array}{l}\text { S16 } \\
\text { (Fo) }\end{array}$ & $\begin{array}{l}\text { S17 } \\
\text { (Fo) }\end{array}$ & $\begin{array}{l}\text { S18 } \\
\text { (Fo) }\end{array}$ & $\begin{array}{l}\text { S19 } \\
\text { (Fo) }\end{array}$ & $\begin{array}{l}\text { S20 } \\
\text { (Fo) }\end{array}$ \\
\hline $\begin{array}{l}\text { S2 } \\
(\mathrm{Cu})\end{array}$ & 0.72 & & & & & & & & & & & & & & & & & & & \\
\hline $\begin{array}{l}\text { S3 } \\
\text { (Cu) }\end{array}$ & 0.67 & 0.55 & & & & & & & & & & & & & & & & & & \\
\hline $\begin{array}{l}\text { S4 } \\
\text { (Cu) }\end{array}$ & 0.5 & 0.46 & 0.67 & & & & & & & & & & & & & & & & & \\
\hline $\begin{array}{l}\text { S5 } \\
\text { (Cu) }\end{array}$ & 0.45 & 0.24 & 0.55 & 0.37 & & & & & & & & & & & & & & & & \\
\hline $\begin{array}{l}\text { S6 } \\
\text { (Gr) }\end{array}$ & 0.42 & 0.43 & 0.62 & 0.67 & 0.45 & & & & & & & & & & & & & & & \\
\hline $\begin{array}{l}\text { S7 } \\
\text { (Gr) }\end{array}$ & 0.85 & 0.85 & 0.63 & 0.56 & 0.34 & 0.47 & & & & & & & & & & & & & & \\
\hline $\begin{array}{l}58 \\
\text { (Gr) }\end{array}$ & 0.86 & 0.74 & 0.55 & 0.53 & 0.34 & 0.45 & 0.79 & & & & & & & & & & & & & \\
\hline $\begin{array}{l}\text { S9 } \\
(\mathrm{Gr})\end{array}$ & 0.82 & 0.76 & 0.57 & 0.5 & 0.29 & 0.42 & 0.86 & 0.84 & & & & & & & & & & & & \\
\hline $\begin{array}{l}\text { S10 } \\
\text { (Gr) }\end{array}$ & 0.88 & 0.82 & 0.63 & 0.56 & 0.27 & 0.24 & 0.86 & 0.93 & 0.75 & & & & & & & & & & & \\
\hline $\begin{array}{l}\text { S11 } \\
\text { (Ho) }\end{array}$ & 0.68 & 0.73 & 0.37 & 0.35 & 0.16 & 0.27 & 0.64 & 0.52 & 0.2 & 0.54 & & & & & & & & & & \\
\hline $\begin{array}{l}\mathrm{S} 12 \\
(\mathrm{Ho})\end{array}$ & 0.49 & 0.47 & 0.65 & 0.3 & 0.23 & 0.37 & 0.51 & 0.67 & 0.63 & 0.6 & 0.63 & & & & & & & & & \\
\hline $\begin{array}{l}\mathrm{S} 13 \\
(\mathrm{Ho})\end{array}$ & 0.62 & 0.64 & 0.63 & 0.37 & 0.14 & 0.36 & 0.63 & 0.72 & 0.53 & 0.61 & 0.71 & 0.62 & & & & & & & & \\
\hline $\begin{array}{l}\mathrm{S} 14 \\
\text { (Ho) }\end{array}$ & 0.98 & 0.68 & 0.38 & 0.36 & 0.15 & 0.3 & 0.65 & 0.74 & 0.08 & 0.52 & 0.72 & 0.69 & 0.79 & & & & & & & \\
\hline $\begin{array}{l}\text { S15 } \\
\text { (Ho) }\end{array}$ & 0.46 & 0.52 & 0.24 & 0.25 & 0.1 & 0.25 & 0.47 & 0.48 & 0.75 & 0.48 & 0.69 & 0.6 & 0.68 & 0.66 & & & & & & \\
\hline $\begin{array}{l}\text { S16 } \\
\text { (Fo) }\end{array}$ & 0.06 & 0.08 & 0.07 & 0.11 & 0.08 & 0.49 & 0.09 & 0.28 & 0.27 & 0.12 & 0.43 & 0.27 & 0.14 & 0.14 & 0.05 & & & & & \\
\hline $\begin{array}{l}\text { S17 } \\
\text { (Fo) }\end{array}$ & 0.1 & 0.13 & 0.14 & 0.22 & 0.18 & 0.23 & 0.14 & 0.4 & 0.1 & 0.05 & 0.04 & 0.09 & 0.1 & 0.05 & 0.1 & 0.04 & & & & \\
\hline $\begin{array}{l}\text { S18 } \\
\text { (Fo) }\end{array}$ & 0.15 & 0.55 & 0.19 & 0.25 & 0.35 & 0.27 & 0.18 & 0.42 & 0.27 & 0.15 & 0.28 & 0.33 & 0.32 & 0.3 & 0.23 & 0.06 & 0.42 & & & \\
\hline $\begin{array}{l}\text { S19 } \\
\text { (Fo) }\end{array}$ & 0.14 & 0.13 & 0.14 & 0.22 & 0.27 & 0.47 & 0.19 & 0.44 & 0.2 & 0.06 & 0.12 & 0.08 & 0.07 & 0.1 & 0.08 & 0.02 & 0.6 & 0.08 & & \\
\hline $\begin{array}{l}\mathrm{S} 20 \\
\text { (Fo) }\end{array}$ & 0.55 & 0.55 & 0.53 & 0.5 & 0.21 & 0.08 & 0.57 & 0.73 & 0.36 & 0.57 & 0.38 & 0.34 & 0.4 & 0.59 & 0.16 & 0.04 & 0.45 & 0.24 & 0.28 & \\
\hline
\end{tabular}

Cu cultivated outfields, Fo, forest lands, Gr grazing lands, Ho homestead garden fields, S sample site

effects of vegetation on soil water and temperature regimes may vary considerably, with significant effects on the SIMF community (Tian et al., 1997). Some important factors influencing the abundance, distribution, and diversity of SIMF communities include soil quality, immediate substrates, and food resource availability (Barros et al., 2002). Ecological imbalance arising from any severe alterations of these factors may affect the natural environment in which SIMF communities live (Dash, 2003; Rybalov, 1990).
The results demonstrate that human disturbances are an important factor influencing macro-fauna community. Generally, this study shows that soil macro-faunas are sensitive to land use and management practices. The reason for this might be connected with the anthropogenic activities that result in disturbance of habitat. The finding of this study is in agreement with (Barrios 2007) who reported that land use can exert a strong influence on the abundance, diversity, and community composition of SIMF. On the other hand, the result of this study disagrees with the findings of 
Table 5 Abundance of SIMF in four land use classes at Shenkolla watershed

\begin{tabular}{llllll}
\hline SIMF & Forest land & Homestead garden field & Grazing land & Crop cultivated outfields & Total abundance \\
\hline Earthworm & 13 & 72 & 53 & 39 & 177 \\
Beetle larvae & 4 & 13 & 0 & 0 & 17 \\
Beetle adult & 6 & 14 & 2 & 2 & 24 \\
Spider & 1 & 2 & 3 & 2 & 8 \\
Ants & 4 & 15 & 4 & 1 & 24 \\
Termites & 26 & 19 & 2 & 0 & 47 \\
Millipede & 4 & 3 & 3 & 1 & 11 \\
Centipede & 3 & 6 & 0 & 0 & 9 \\
Earwig & 4 & 0 & 0 & 0 & 4 \\
Snails & 1 & 3 & 0 & 0 & 4 \\
Grasshopper & 5 & 0 & 0 & 0 & 5 \\
Wireworm & 2 & 0 & 0 & 0 & 2 \\
Over all abundance & 73 & 148 & 67 & 44
\end{tabular}

(Manetti et al., 2010) who explained that tillage system does not affect soil macro-fauna in the southeastern Buenos Aires Province, Argentina.

Our study seems to indicate that maintenance of a continuous litter cover at the surface, application of a wide range of organic fertilizers (farmyard manure, household refuse, and compost), and minimizing compaction and over all disturbance of habitat may prevent the decrease in diversity of SIMF.

\section{Conclusions}

Results obtained from this study demonstrate that quantitative changes in the abundance and diversity of SIMF communities occur when land is intensively cultivated. The resultant changes are associated with management practices that consequently result in habitat destruction and removal of organic substrate hence reduced availability of food sources for associated SIMFs. Forest land is relatively rich in terms of species of SIMF and high abundance was noted in the homestead garden fields. Of all the land use classes, crop cultivated outfields differed most from the others, recording relatively low taxonomic richness, and evenness. Therefore, practicing of sustainable cropping systems that maintain acceptable levels of SIMF abundance and that may minimize the level of human disturbances are desirable in this watershed to optimize their activities and their impacts on soil fertility. This requires the integration of knowledge of biological processes into the design of land management systems. More detailed studies are also needed to identify the

Table 6 Coefficients of linear model analysis

\begin{tabular}{lllll}
\hline Coefficients: & Estimate & Std. error & $\boldsymbol{t}$ value & Pr $(>|\mathbf{t}|)$ \\
\hline (Intercept) & 96 & 69 & 1.391 & 0.173 \\
Centiped & -60 & 97.58 & -0.615 & 0.543 \\
Adult coleopteran & -4 & 97.58 & -0.041 & 0.968 \\
Coleoptera larvae & -28 & 97.58 & -0.287 & 0.776 \\
Earthworm & 596 & 97.58 & 6.108 & $4.99 \mathrm{e}-07^{* * *}$ \\
Earwig & -80 & 97.58 & -0.82 & 0.418 \\
Grasshopper & -68 & 97.58 & -0.0697 & 0.49 \\
Millipede & -52 & 97.58 & -0.533 & 0.597 \\
Snail & -80 & 97.58 & -0.82 & 0.418 \\
Spider & -64 & 97.58 & -0.656 & 0.516 \\
Termite & 92 & 97.58 & 0.943 & 0.352 \\
Wireworm & -88 & 97.58 & -0.902 & 0.373 \\
\hline
\end{tabular}


best possible combination of land use and the varying management practices in different land use to allow the most desirable sustainability of SIMF.

\author{
Abbreviations \\ ANOVA: Analysis of variance; Cu: Cultivated outfields; DAP: Di-ammonium \\ phosphate; Fo: Forest lands; GLMs: Generalized linear models; Gr: Grazing \\ lands; Ho: Homestead garden fields; NOI: Number of occurrence index; \\ SIMF: Soil invertebrate macro-fauna; SPSS: Statistical Package for Social \\ Science
}

\section{Acknowledgements}

The authors wish to thank the Center for Environmental Sciences, Addis Ababa University, and Wachemo University, for providing funds and facilities. Finally, the authors would also like to express their gratitude to the editor and anonymous reviewers for their comments, which greatly improved the quality of this manuscript.

\section{Authors' contributions}

BB carried out designing the research idea, method design, field data collection, data analysis and interpretation, prepare draft of the manuscript, and structuring the report; EE and EG supervised the inception and designed and edited the manuscript. All authors have read and approved the final manuscript.

\section{Authors' information}

Belayneh Bufebo is a PhD candidate in Environmental Science at Addis Ababa University and lecturer at the Department of Natural Resource Management in Wachemo University. He has given Introduction to Environmental Science, Introductory Soils, Land degradation and rehabilitation, Environmental Impact Assessment courses, and also published more than 5 articles in internationally peer-reviewed journals. Eyasu Elias (PhD) is an associate professor of Environmental Science at the College of Natural Science in Addis Ababa University. His specialization is soil science. He teaches courses on land degradation and restoration ecology. Dr. Eyasu Elias has published several peer-reviewed papers on soil fertility, land degradation, and land use change impacts.

Emana Getu is a professor of Entomology Department of Zoological sciences at the College of Natural Science in Addis Ababa University. He has published several peer-reviewed papers in internationally peer-reviewed journals.

\section{Funding}

Addis Ababa University supported finance for field data collection and Wachemo University provided financial and other material support during the study

\section{Availability of data and materials}

All data are available upon request.

\section{Ethics approval and consent to participate}

Not applicable.

\section{Consent for publication}

Not applicable.

\section{Competing interests}

The authors declare that they have no competing interests.

\section{Author details}

'Department of Natural Resource Management, Wachemo University, P.O. Box 667, Hosanna, Ethiopia. ${ }^{2}$ Center for Environmental Science, College of Natural and Computational Sciences, Addis Ababa University, Addis Ababa, Ethiopia. ${ }^{3}$ Department of Zoology, College of Natural and Computational Sciences, Addis Ababa University, Addis Ababa, Ethiopia.
Received: 15 March 2020 Accepted: 6 January 2021

Published online: 01 February 2021

\section{References}

Anderson, J. M., \& Ingram, J. S. I. (Eds.) (1993). Tropical soil biology and fertility: A handbook of methods, (2nd ed., ). Wallingford: CAB International.

Ayuke, F. O., Brussaard, L., Vanlauwe, B., et al. (2011). Soil fertility management: Impacts on soil macro-fauna, soil aggregation and soil organic matter allocation. Applied Soil Ecology, 48(1), 53-62.

Ayuke, F. O., Karanja, N. K., Muya, E. M., et al. (2009). Macro-fauna diversity and abundance across different land use systems in Embu, Kenya. Tropical and Subtropical Agroecosystems, 11, 371-384.

Barrios, E. (2007). Soil biota, ecosystem services and land productivity. Ecological Economics, 64, 269-285.

Barros, E., Pashanasi, B., Constantino, R., \& Lavelle, P. (2002). Effects of land-use system on the soil macro-fauna in western Brazilian Amazonia. Biology and Fertility of Soils, 35, 338-347.

Beare, M. H., Reddy, M. V., Tian, G., \& Srivastava, S. C. (1997). Agricultural intensification, soil biodiversity and agroecosystem function in the tropics: The role of decomposer biota. Applied Soil Ecology, 6, 87-108.

Bignell, D. E., Constantino, R., Csuzdi, C., et al. (2008). Macrofauna. In F. M. S. Moreira, J. E. Huising, \& D. Bignell (Eds.), A handbook of tropical soil biology: Sampling and characterization of below-ground biodiversity (pp. 43-83). Clerkenwell: Earthscan.

Bignell, D. E., Tondoh, J., Dibog, L., et al. (2005). Below-ground biodiversity assessment developing a key functional group approach in bestbet alternatives to slash and burn. In C. A. Palm, S. A. Vosti, P. A. Sanchez, \& P. J. Ericksen (Eds.), Slash and burn agriculture: The search for alternatives (pp. 119-142). New York: Columbia University Press p.

Bray, J. R., \& Curts, J. T. (1957). An ordination of the upland forest communities in southern Wisconsin. Ecological Monographs, 27, 325-349.

Brown, G., Pashanasi, B., Gilot-Villenave, C., et al. (1999). Effects of earthworms on plant growth in the tropics. In P. Lavelle, L. Brussaard, \& P. Hendrix (Eds.), The management of earthworms in tropical agroecosytems, (pp. 87-148). Wallingford: CAB International.

Brown, G. G., Moreno, A. G., Barois, l., et al. (2004). Soil macro-fauna in SE Mexican pastures and the effect of conversion from 551 native to introduced pastures. Agro Ecosystems \& Environment, 103, 313-327.

Bufebo, \& Elias (2020). Effects of land use/land cover changes on selected soil physical and chemical properties in Shenkolla watershed, south Central Ethiopia. Advances in Agriculture, 2020, 1-8. https://doi.org/10.1155/2020/ 5145483.

Dash, M. C. (2003). Fundamental of ecology, (2nd ed., ). New Delhi: Tata McGrawHill publishing company limited.

Decaëns, T., Jiménez, J. J., Barros, E., et al. (2004). Soil macro-faunal communities in permanent pastures derived from tropical forest or savanna. Agriculture, Ecosystems and Environment, 103(2), 301-312.

Decaëns, T., Lavelle, P., Jimenez, J. J., et al. (1994). Impact of land management on soil macrofauna in the oriental llanos of Colombia. European Journal of Soil Biology, 30, 157-168.

Eaton, E. R., \& Kaufman, K. (2007). Kaufman field guide to insects of North America. New York: Hillstar Editions.

Elias, E. (2016). Soils of Ethiopian high lands: Geomorphology and properties, (p. 385). The Netherlands: CASCAPE project, ALTERA. Wageningen: Wageningen University and Research Centre (Wageningen UR).

Elias, E. (2018). Selected chemical properties of agricultural soils in the Ethiopian highlands: A rapid assessment. South African Journal of Plant and Soil. https:// doi.org/10.1080/02571862.2018.1506829.

Elias, P. F., Okothc, E. M. A., \& Smalingd (2019). Explaining bread wheat (Triticum aestivum) yield differences by soil properties and fertilizer rates in the highlands of Ethiopia. https://doi.org/10.1016/j.geoderma.2018.12.020.

Landon (1991). Booker tropical soil manual: A handbook for soil survey and agricultural land evaluation in the tropics and subtropics, (p. 474). Essex, New York: Longman Scientific and Technical.

Lavelle, P., Dangerfield, M., Fragoso, C., et al. (1994). The relationship between soil macro-fauna and tropical soil fertility. In P. Woomer \& M. Swift (Eds.), The biological Management of Tropical Soil Fertility (pp. 137-170). Chichester: Wiley.

Lavelle, P., Senapati, B., \& Barros, E. (2003). Soil macro-fauna. In G. Schroth, \& F. L. Sinclair (Eds.), Trees, crops and soil fertility: Concepts and research methods, (pp. 303-323). Wallingford: CAB International. 
Manetti, P. L., López, A. N., Clemente, N. L., \& Faberi, A. J. (2010). Tillage system does not affect soil macrofauna in southeastern Buenos Aires province, Argentina. Spanish Journal of Agricultural Research, 8(2), 377-384.

Manhães, C. M. C., Gama-Rodriques, E. F., Moço, M. K. S., et al. (2013). Meso-and macrofauna in the soil and litter of leguminous trees in a degraded pasture in Brazil. Agroforestry Systems, 87(5), 993-1004.

Margalef, R. (1968). Perspective in ecological theory Uni. Of Chicago Press, (p. 112).

Moreira, F. M., Huising, E. J., \& Bignell, D. (2008). A handbook of tropical soil biology: Sampling and characterization of below-ground biodiversity. London: Earthscan.

Muchane, N. M., Karanja, D., Wambugu, G. M., et al. (2012). Land use practices and their implications on soil macro-fauna in Maasai Mara ecosystem Nairobi, Kenya. International Journal of Biodiversity and Conservation, 4(13), 500-514.

Mutema, M., Mafongoya, P. L., Nyagumbo, l., \& Chikukura, L. (2013). Effects of crop residues and reduced tillage on macrofauna abundance. Journal of Organic Systems, 8(1), 16.

Negasa, T., Ketema, H., Legesse, A., Sisay, M., \& Temesgen, H. (2017). Variation in soil properties under different land use types managed by smallholder farmers along the toposequence in southern Ethiopia. 290(20170): 40-50.

New, T. R. (2005). Invertebrate conservation and agricultural ecosystems. Cambridge: Cambridge University Press.

Pielou, E. C. (1966). Species diversity and pattern diversity in the study of ecological succession. Journal of Theoretical Biology, 10, 370-383.

Rossi, J. P., Celini, L., Mora, P., et al. (2010). Decreasing fallow duration in tropical slash-and-burn agriculture alters soil 660 macro invertebrate diversity: A case study in southern French Guiana. Agriculture, Ecosystems \& Environment, 135, $148-154$

Rybalov, L. B. (1990). Comparative characteristics of soil macrofauna of some tropical savannah communities in equatorial Africa: Preliminary results. Tropical Zoology, 3(1), 1-11. https://doi.org/10.1080/03946975.1990.10539445.

Seeber, J., Seeber, G. U. H., Kössler, W., et al. (2005). Abundance and trophic structure of macro-decomposers on alpine pastureland (Central Alps, Tyrol): Effects of abandonment of pasturing. Pedobiologia, 49, 221-228. https://doi. org/10.1016/j.pedobi.2004.10.003.

Shannon, C. E., \& Weaver, W. (1949). The mathematical theory of communication (p. 144). Urbana: University of Illinois Press.

Simpson, E. H. (1949). Measurement of diversity. Nature, 163, 688

SPSS (Statistical Package for Social Science) (2007). SPSS for windows release 16.01. Standard version SPSS, Inc., 1989-2007.

Tian, G., Kang, B. T., \& Brusaard, L. (1997). Effect of mulch quality on earthworm activity and nutrient supply in the humid tropics. Soil Biology and Biochemistry, 29, 369-373.

Tondoh, E. J., \& Lavelle, P. (2005). Population dynamics of Hyperiodrilus africanus (Oligochaeta, Eudrilidae) in Ivory Coast. Journal of Tropical Ecology, vol, 21, 493-500.

Wardle, D. A., Bardgett, R. D., Klironomos, J. N., et al. (2004). Ecological linkages between aboveground and belowground biota. Science., 304(5677), 16291633.

Zettler, J. A., Mateer, S. C., Link-Pérez, M., et al. (2016). To key or not to key: A new key to simplify \& improve the accuracy of insect identification. The American Biology Teacher, 78(8), 626-633 http://www.bioone.org/doi/full/10.1525/abt.2 016.78.8.626.

\section{Publisher's Note}

Springer Nature remains neutral with regard to jurisdictional claims in published maps and institutional affiliations.

\section{Submit your manuscript to a SpringerOpen ${ }^{\circ}$ journal and benefit from:}

- Convenient online submission

- Rigorous peer review

- Open access: articles freely available online

- High visibility within the field

- Retaining the copyright to your article

Submit your next manuscript at $\boldsymbol{\nabla}$ springeropen.com 